\title{
Strategic Research for Talent Cultivation of Strategic Emerging Industries under Industry 4.0
}

\author{
Yutai Rao ${ }^{1, a}$ and Fan Yang $2, \mathrm{~b}^{*}$ \\ 1 Dean's Office, Hubei Radio \& TV University, Wuhan, Hubei, 430074, China \\ 2 Software Engineering Institute, Hubei Radio \& TV University, Wuhan, Hubei, 430074, China \\ a2079406@qq.com, byangfan_sheep@163.com
}

Keywords: Industry 4.0; strategic emerging industry; talent cultivation strategy

\begin{abstract}
The shortage of talented people in strategic emerging industries under Industry 4.0 is an important factor restricting industrial development. According to the requirements of national vocational education to serve the local economy, this paper analyzes the shortage of talents in Hubei. From the needs analysis of job types and professional types, the strategy of talent cultivation should focus on the construction of industrial professional groups, the cooperation of government, school, business and industry, the integration of modern apprenticeships and the cultivation of dual-creation skills.
\end{abstract}

\section{Introduction}

Industry 4.0, also known as the fourth industrial revolution, is one of the ten future projects proposed by the German government's "Germany 2020 High Technology Strategy". It covers three major themes, one is smart factory and the other is intelligent production. The third is intelligent logistics [1].China's strategic emerging industries are based on major technological breakthroughs and major development needs. They have important tie-making actions for economic and social overall and long-term development, industries with intensive knowledge and technology, low consumption of material resources, large growth potential, and comprehensive benefits. The Outline of the Thirteenth Five-Year Plan for National Economic and Social Development of the People's Republic of China and China Manufacturing 2025 clearly point out the importance of developing intelligent production and strategic new industries, and improving industrial level and efficiency [2].The provincial government of Hubei Province issued the "Hubei Province trillions of strategic emerging industry promotion implementation plan" proposed to strive to increase the value of the province's strategic emerging industries by more than $17 \%$ of GDP by 2020, a new generation of information technology, biology, high-end equipment, new The sum of the main business income of 16 key areas of materials, green low-carbon and digital creative has exceeded 3 trillion, and the strategic emerging industries have been cultivated as the main driving force of economic development, making Hubei the core of strategic emerging industries in the central region. District, national strategic emerging industry development highland [3].The talent cultivation of strategic emerging industries under Industry 4.0 has far-reaching influence on the development of strategic emerging industries in our province, and is of great significance for accelerating the realization of the strategic goal of manufacturing strong countries. At present, Chinese scholars are still in the stage of exploration in this context, and the research on talent cultivation in strategic emerging industries under Industry 4.0 has far-reaching practical significance..

\section{Talent Demand Analysis}

For example, in the catalogue of the shortage of talents in the new generation of information technology industry listed in the Catalogue of Demanding Talents for Strategic Emerging Industries in Hubei Province in 2016, there are three types of jobs that are urgently needed, namely, 188 professional and technical positions, and management and management positions. There are 55 high-skilled jobs, including 65 professional and technical posts and nearly 50 different majors. The management covers 
nearly 20 different majors [4].Table 1 shows the statistics of the shortage of talents in the new generation of information technology industry in Hubei. The data shows that the development focus of the new generation information technology industry in Hubei Province is still in the provincial capital city of Wuhan, and the demand for professional and technical positions and high-skilled jobs is greater than that for management and management.

Table 1 Demand for talent shortage in a new generation of information technology industry across Hubei

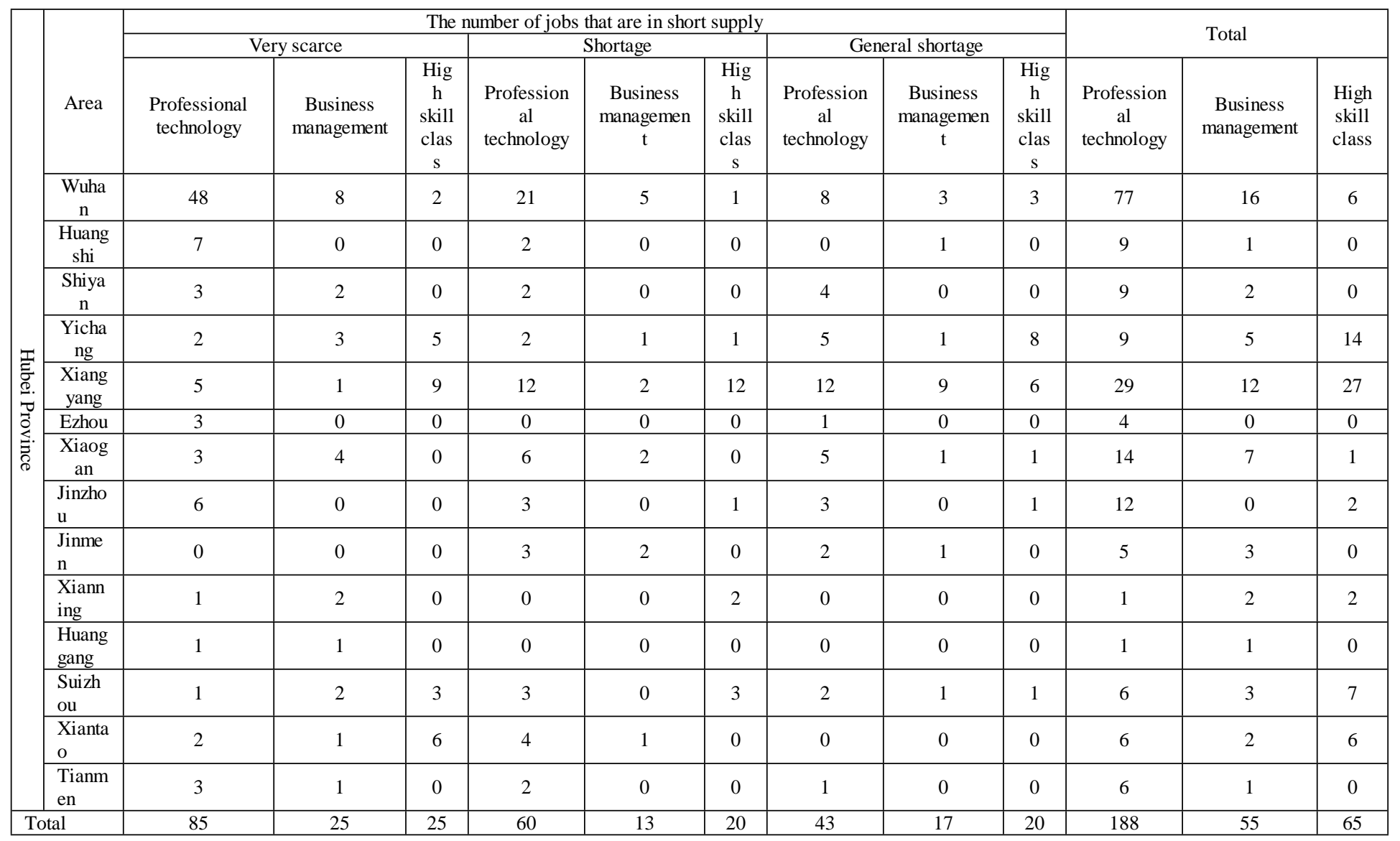

The data shows that the talent demand of a strategic emerging industry is not satisfied by a certain discipline professional group. It involves majors in various disciplines such as majors, economics, and design. The cultivation of professional talents can also focus on a certain level of high-skilled training. In the economics, design and other professional fields, it is also necessary to properly integrate the expertise of some industries. The data also shows that the talent demand of a strategic emerging industry will still be dominated by professional talents, supplemented by other talents. From this we can see the leading role of industrial development.

\section{Talent Cultivation Strategy}

Vocational education should focus on the construction and development of industrial professional groups. China's vocational education must serve the local economy, and the development of the local economy in turn affects the cultivation of talents in vocational education. Both must develop healthily. The talent demand of a certain type of strategic emerging industry is no longer provided by the professional group in the academic sense, but is provided by various professions required by this industry. This article refers to the construction of industrial professional groups. These professions are not necessarily the same. The same professional category. For example, the talents needed in the new generation of information technology industry in Hubei Province cover a number of majors under the 
professional categories of electronic information, economic management, art design, and mechanical manufacturing. This requires horizontal consideration of the continuous development of the industrial professional group when cultivating talents. This will minimize the gap between the talents cultivated by the school and the actual needs of the company. Vocational education can be done in two ways. First, professional counterparts in the industry, For example, if you are training an electronic information professional, you should integrate some knowledge of management and design. The other is in the industry to assist professionals, If the management and design professionals are trained, they should be properly integrated into the industry's counterpart expertise. This makes it easy for students to know what they actually do in their future jobs at school.

Vocational education should pay attention to the cooperation and training of government schools and enterprises. Vocational education should be able to accurately serve the local economy. The development of local economy should be able to effectively promote the development of vocational education. Therefore, schools need to understand policies and trends in real time. It is necessary to understand the needs of enterprises in a timely manner, and it is necessary to grasp the industry dynamics in real time. This requires the cooperation and training of political schools and enterprises. This is different from the traditional school-enterprise cooperation model. In the context of the current Internet + era, the mastery of information and information is the first important. Especially important for vocational education. The government, enterprises, and industries can provide information and help to run schools from different levels. Such vocational education can also be truly integrated into the local economic development, and can truly play the positive role of education.

Vocational education should focus on the integration of modern apprenticeship. The school trains talents for enterprises. In order to enable graduates to be more qualified for practical jobs, in addition to traditional internships, students should be alternated in their normal education. The teachers of the school and the masters of the company should undertake the task of stable teachers. Adopt modern apprenticeship system to let students work from learn and learn from work. Under the background of the joint operation of government schools and enterprises, the students' tutors cannot be as simple as before, only the teachers of the school. Teachers from government, enterprises, and industry can become his mentor. Give him help from different angles so that when he is at school, he can get the guidance of the master like a company. Before graduation, you will be able to understand what problems will be encountered in future jobs and how to solve them.

Vocational education should pay attention to the cultivation of talents' innovation and entrepreneurship. Strategic emerging industries are leading the development of national industries, and the essence requires innovation. The cultivation of future talent creation ability can optimize the comprehensive quality of talents, so that in addition to being able to be qualified for jobs, they can adapt to changes in jobs in the future. At the same time, having dual ability also means having superior learning ability, which also has positive significance for the development of emerging industries and the development of talents themselves. The ability to innovate allows talent to be sustainable and to keep the industry alive. The ability to start a business allows talents to create more industries, and can quickly develop a frontier industry that is more responsive to future social needs. No matter what kind of industry in the future, the ability and spirit of innovation and entrepreneurship are needed.

\section{Summary}

In order to solve the shortage of talents in strategic emerging industries, vocational education must not only accurately cultivate the talents needed by the industry, but also shorten the time when students graduate to be qualified for their jobs. The professional talents involved in the strategic emerging industries under Industry 4.0 should have a tendency to join the knowledge of other professions in the professional group of the industry. It is necessary to focus on multi-party collaborative training of talents, not to fight alone, and to integrate in the context of government school enterprise industry cooperation. The cultivation of modern apprenticeship and dual-creation ability can effectively improve the efficiency and quality of talent cultivation. 


\section{Acknowledgements}

In this paper, the research was sponsored by the 2015 project of Hubei education scientific planning (Project No.2015GB346): Research and Practice on Talent Cultivation Model of Strategic Emerging Industry Innovation and Entrepreneurship Education under Modern Apprenticeship System-Taking Internet of Things as an Example. Associate Professor Fan Yang of Hubei Radio \& TV University is the Corresponding Author of this paper, her email is yangfan_sheep@163.com.

\section{References}

[1] German government, Germany 2020 high-tech strategy,.(2010)

[2] The Chinese Government, Thirteenth Five-Year Plan for National Economic and Social Development of the People's Republic of China,(2017), and Made in China 2025.(2018)

[3] Hubei Province Provincial Government, Hubei Province trillion strategic emerging industry promotion implementation plan. (2017)

[4] Hubei Provincial Bureau of Statistics, 2016 Hunan Province Strategic Emerging Industry Shortage Talent Demand Catalogue.(2016)

[5] Chen Haiping. Research on the demand for talents in the development of strategic emerging industries.Social Aspects (New Theory Edition). 2012, (9): 58-59.

[6] Xiao Shuguang. Labor distribution of strategic emerging industry organizations [J].National Industrial Economy, 2011 (2): 100-109.

[7] Shi Xiuhua.US and European scientific and technological talent team construction experience and its enlightenment to Hubei [J].Scientific and technological progress and countermeasures, 2011, 28 (12): 187-189.

[8] Yuan Dezhi. Research on the training of pilot talents [J].Guangdong Chemical Industry, 2013.24.

[9] Li Ling, Yan Hairan. Research on industry-university-research cooperation and strategic emerging industry talent development path [J]. Journal of Fuzhou University (Philosophy and Social Sciences Edition), 2013.1.

[10] Wang Xiaoqin. Reflections on the countermeasures for the construction of talented teams in strategic emerging industries in Daqing City. Daqing Social Science, 2013.3. 